\title{
İktisadî Kalkınma Yolunda Öncü Bir Danışma Organı: Âlî İktisat Meclisi
}

\author{
Özlem YAKTI* \\ Perihan ÜNLÜ SOYLU*
}

\begin{abstract}
Özet
Türk Hükümeti, 1920'li yılların sonunda gerek özel girişimin elindeki sermaye birikiminin yetersizliği, gerekse de 1929 dünya buhranı sonucu artan iflaslar nedeniyle özel kesimin beklenen sanayileşmeyi gerçekleştiremeyeceğini düsünmüşü̈r. İktisadi politika arayışları kurulan Serbest Fırka'nın beklenenden fazla ilgi görmesiyle hızlanmış ve sanayileşmenin hızlandırılması aynı zamanda siyasi bir gereklilik olmuştur. Serbest piyasa ekonomisi çerçevesinde sadece piyasa güçleri ile ulusal bir iktisat politikası izlenemeyeceği açıtır. Bu amaçla politik kararların alınacağl, gerekli bilgilerin sağlanacağl ve baskı gruplarının da karar alma sürecine dâhil edileceği kurumlara ihtiyaç duyulmaya başlanmıştır. Bu çalışmada kurumsallaşma çabaları sonucunda kurulmuş örgütlerden biri olan Âli İktisat Meclisi (ÂIM) konu edilmiştir. 19. yüzyllda Avrupa'da kurulan örnekleri gibi Türkiye'de kurulan ÂIM'nin de iktisadi açıldan düzenleme ve geliştirme amaclyla gerçekleştirilmesi gereken iktisadi gelişmeleri tespit ederek bir program oluşturmast beklenmiştir. 1927 yllında kurulan ÂIM'nin yaptı̆̆ çalışmalarla Türk iktisat tarihi içinde önemli yere sahip kanunların hazırlanması ve örgütlerin kurulmasında etkili olduğu söylenebilir. Bu nedenle çalışma ÂIM'ni ortaya çıkaran iç ve diş koşulları betimleyen kisa bir açılama ile başlamakta ve ÂIM'nin araştırmaları sonucunda hazırlanan raporların önemli sonuçlarını vurgulamaktadır. Ülke genelinde araştırmalar yaparak, sanayi ve ticaret alanına ilişkin raporlar hazırlayan ÂIM, Avrupa'daki örneklerinden farklı olarak, sinıfsal çıkar çatışmalarını uzlaştırmaktan ziyade özel kesimin bazı isteklerinin hükümete intikali için bir kanal olmuştur.
\end{abstract}

Anahtar Kelimeler: Âlî Iktisat Meclisi, Şakir Kesebir plânl, Âlî İktisat Meclisi Raporlarl, 1929 Dünya Buhrani, Sümerbank ve KIT.

\footnotetext{
* Ankara Üniversitesi, Türk İnkılâp Tarihi Enstitüsü Doktora Öğrencisi.

* Ankara Üniversitesi, Türk İnkılâp Tarihi Enstitüsü Doktora Öğrencisi.
} 
A Pioneering Consultation Organ On The Path of Economic Development: Supreme Assembly of Economics

\section{Abstract}

For both the deficiency of the capital accumulation in the hands of the private enterprise and the increasing bankruptcies happening due to the 1929 Great Depression as well, Turkish Government had considered that the private enterprise wouldn't realize the expected industrialization. The trials for the economic policies had accelerated by the founded Free Republican Party's (FRP) support more than the expected and the acceleration of the industrialization had become a political necessity as well. This study evaluates the Supreme Assembly of Economics (SAE), an organization which had been founded as a result of the institutionalization attempts. Like the examples founded in the 19th century, Europe, it had been expected that the SAE's commitment of a program by the aim of the organization and development economically. It can be mentioned that SAE had been effective on the establishment of the important organizations and the laws in the Turkish Economic History. For this reason, the study begins with a short explanation describing the domestic and foreign reasons exposing $S A E$ and underlines the important results of the reports prepared by the inquiries of SAE. Preparing reports about the industrial and commercial fields by committing inquiries in whole of the country, SAE, unlike its counterparts in Europe, had been a channel for the transition of the demands of the private enterprise through the Government than the conciliation of the interests of the class conflicts.

Key Words: Supreme Assembly of Economics, Şakir Kesebir Plan, The Reports of The Supreme Assembly of Economics, The 1929 Great Depression, Sümerbank and Public Economic Enterprise(s)

\section{GİRIŞ̧}

Kurtuluş Savaşı sona erdiğinde, gerek Osmanlı döneminin olumsuz politika uygulamaları gerekse de ardarda yaşanan savaşlar nedeniyle ülke kaynakları tükenmiştir. Sanayisi olmayan ülkede, var olan işletmelerin de yabancıların elinde olması nedeniyle halk yoksuldur. Halkın temel ihtiyaç maddeleri bile dișarıdan temin edilmektedir. Elindeki son imkânları kullanarak kurtuluş mücadelesini kazanan genç Türkiye Cumhuriyeti'nin, refaha ulaşabilmesi için bir ekonomi ve kalkınma savaşı vermesi gerekecektir. ${ }^{1}$

\footnotetext{
${ }^{1}$ Mehmet Burak Durdu, "Camilla Jaquart'ın Raporuna Göre Atatürk Döneminde Türk Ekonomisi”, Kastamonu Eğitim Dergisi, C. 16, No:1, ( Mart 2008), s.22.
} 
Ekonomik kalkınma yolunda önemli bir tarihsel dönemeç olan Türkiye İktisat Kongresi'nde yeni Türkiye Devleti'nin iktisat politikalarını belirleyecek kararlar alınmıştır. ${ }^{2}$ Bu kongrenin açış konuşmasında Atatürk: "Siyasî ve Askerî zaferler ne kadar büyük olursa olsun, iktisat zaferleriyle taçlandirlmazlarsa elde edilen zaferler sürüp gidemez, az zamanda söner",3 diyerek, iktisadî bağımsızlıkla siyasî bağımsızlığın birbirinin ayrılmaz parçası olduğunu vurgulamıştır.

Meclisin üçüncü açış yılı olan 1 Mart 1922'de yaptığı konuşmasında izlenecek olan iktisadî politikada "devletçilik" i vurgulayan Atatürk, Türkiye İktisat Kongresi'ndeki açış konuşmasında ise devletçiliğe değinmediği gibi, özel girişimlerden de bahsetmemiştir. Kongrede Atatürk'ün önemle vurguladığı tek konu, iktisadın ülke kalkınmasındaki önemi ile yeni Türkiye Devleti'nin bir iktisat devleti olması için iktisadi konuların tartışılmasına öncelik verilmesinin gerekliliğidir. ${ }^{4}$ Kongrede İktisat Bakanı Mahmut Esat Bozkurt, karma ekonomi modelinden söz ederek, iktisadi girişimlerin kısmen devlet, kısmen de özel girişim tarafindan üstlenilmesi gerektiğini vurgulamıştır. Bu durum 1929'a kadar ülkenin genel ekonomi politikasını belirlemiş ve zaman zaman devletin ekonomiye müdahalesini de içinde barındıran bir liberal iktisadi politika izlenmiştir. İzlenen bu politika gereği hükümet, 1920'lerden itibaren özel birikime elverişli bir ortam yaratacak, doğrudan destek sağlayacak, bazı önemli çıkar çevrelerinin eğilimlerini yansıtacak ve iktisat politikası kararlarının hazırlanmasına yardımcı olacak yeni örgütler kurmuştur. ${ }^{5}$ İktisat politikalarının özel girişimciliği desteklemeye öncelikle yöneldiği bir dönemde (25 Haziran 1927), kurulan Âlî İktisat Meclisi ${ }^{6}$ (ÂìM) de bu örgütlerden biridir. ${ }^{7}$

\section{İktisadî Alanda Örgütlenme: Âlî İktisat Meclisi’nin Kurulması}

Âli İktisat Meclisi; 19. yy başlarında Fransa, Almanya, İtalya gibi ülkelerde görülen, çeşitli bask1 gruplarının yer aldığı ve iktisat politikasının şekillenmesi amacıyla oluşturulmuş yardımcı bir kuruluştur. Daha çok

\footnotetext{
${ }^{2}$ Afet İnan, İzmir İktisat Kongresi (17 Şubat-4 Mart 1923), Ankara, TTK Basımevi, 1989, s.12-13; Yüksel Ülken, Atatürk ve Íktisat, Ankara, Türkiye İş Bankası Kültür Yayınları, 1981, s.83.

3 Ali Sevim(Haz.), Atatürk'ün Söylev ve Demeçleri, Ankara, Atatürk Araştırma Merkezi, 2006, s. 466-478

${ }^{4}$ Ülken, s.226.

${ }^{5}$ Yahya Sezai Tezel, Cumhuriyet Döneminin İktisadi Tarihi (1923-1950), 3. Baskı, İstanbul, Yurt Yayınları, 1994, s.229.

${ }_{7}^{6}$ Âli İktisat Meclisi'nin diğer adı Yüksek Ekonomi Kurulu olarak bilinmektedir.

7 Meral Tecer, "Atatürk Döneminde (1923-1938) Ekonomik Örgütlenme", Amme İdaresi Dergisi, Cilt. 39, say1 4, Aralık 2006, s.112.
} 
danışma organı niteliği taşıyan Âlî İktisat Meclisinin bir örneği 1927 tarih ve 1170 sayılı kanunla ülkemizde oluşturulmuş; 1935 yılında 2735 sayılı bütçe kanununun 25. Maddesiyle de yürürlükten kaldırılmıştır. ${ }^{8}$

İktisat Vekili Mustafa Şeref Bey, 3.12.1930 tarihinde ÂİM'nin açışında yaptığı konuşmasında özel sanayi, ticaret ve madencilik yatırımlarının teşvik edilmesi ve ülkenin içinde bulunduğu sorunlara yönelik çözümlerin araştırılması gibi amaçlar doğrultusunda, Başbakanlığa bağlı bir danışma kurulu olarak faaliyete geçen ÂİM'nin ${ }^{9}$ kuruluş amacına yönelik şu açıklamalarda bulunmuştur:

"Size arz edebilirim ki dün iktisadî işlerde -Gölge etme başka ihsan istemem- diyen bir vatandaş, bugün gerek tek tek meseleler hakkında ve gerek sistem vücuda getirebilecek umumi esaslar hakkında devletten daima müdahale ve himaye talep etmektedir. Gün geçmiyor ki; Iktisat Vekili sıfatı ile bir vatandaşın iktisadi bir mesele üzerinde müdahale ve himaye talebi ile karşılaşmayayım. Gene gün geçmiyor ki, devlet reisi veya hükümet reisi tarafindan bendenize havale edilen iktisadi işlere ait vatandaş istidalartyla karşılaşmayayım. Bütün bunlar devlet camiasına dâhil fertlerin ve grupların devlet vazifeleri hakkında düşüncelerinde, bir değişiklik olduğunu gösterir. Bu değişiklik devletin uzuvları üzerinde etkisini gösterecektir. İşte bu tesir ve icaptan Âli Ikktisat Meclisi oluştu." "10

Âlî Meclis kanun tasarısının 24 Mart 1927 tarihli gerekçesinde; Âlî Meclis'in kurulmasına neden gerek görüldüğü açıklanmıştır. Gerekçeye göre, Birinci Dünya Savaşı'na katılan bütün ülkeler, savaş bitiminden sonra azalan üretim güçlerini, kaynaklarını ve araçlarını; yeni oluşan koşullarda düzenlemek için, iktisat şuraları oluşturmuşlardır. Bu amaç doğrultusunda, Türkiye'de de ülkenin genel iktisadi gelişimini inceleyerek hızla ilerlemesini sağlamak amaciyla alanında uzman kişilerden oluşan bir kurul oluşturulması zorunlu görülmüsştür.

ÂİM kuruluş kanununun dikkat çeken sekizinci maddesinde, mecliste Başbakanlıkça belirlenen gündem maddelerinin takip edileceği ve meclis üyeleri tarafindan teklif edilecek konularda da Başbakanlık onayının aranacağı belirtilmiştir. Bu bağlamda, bir iktisadi program oluşturulmasının

\footnotetext{
${ }^{8}$ Korkut Boratav, Türkiye'de Devletçilik, 2. Baskı, Ankara, İmge Kitabevi, 2006, s.132; 1170 No'lu Âlî İktisad Meclisi Hakkında Kânun (24 Temmuz 1927 Tarih, 640 sayılı T.C. Resmi Gazete)

9 Boratav, a.g.e., s.132.

${ }^{10}$ Bilsay Kuruç, Belgelerle Türkiye Íktisat Politikası (1929-1932), c.1, Ankara, Ankara Üniversitesi Siyasal Bilgiler Fakültesi Yayınları, 1988, s.126.
} 
gündeme alınması ya hükümetçe teklif edilmiş veya onun bilgisi ve desteği ile olmuştur.

Değiş̧ik devlet daireleri arasında uyum sağlaması düşünülen Meclis, 12'si Bakanlar Kurulunca iktisadi konularda yetkinlikleri kabul edilen kişiler arasından, diğer 12'si Ticaret ve Sanayi Odaları ile Meslek Teşekkülleri arasından seçilen toplam 24 üyeden oluşmaktadır. Birinci fahri başkanı Başbakan, ikinci fahri başkanı İktisat Bakanıdır. Hükümet kontrolündeki Meclis'in bileşimine ilişkin bu hüküm, sınıfsal ya da mesleki, tüm toplum kesimlerinin kapsanmasına uygun bir ortam sağliyorsa da, böyle bir üye yapısına ulaşılamamış ve temsil edilen gruplar arasında işçi kesimi gibi toplumun güçsüz grupları temsil olanağı bulamamıştır. ${ }^{11} \mathrm{Bu}$ nedenle altı ayda bir 15 gün için toplanan Âlî Meclis, Avrupa'daki örneklerinden farklı olarak, sınıfsal çıkar çatışmalarını uzlaştırmanın dışında özel kesimin bazı isteklerinin hükümete ulaştırılmasında aracı rolü üstlenmiştir. Daha çok araştırmaya dönük olması nedeniyle tutucu ve pasif bir kurum olarak kalan Âli Meclis'e yerine getirmesi beklenen şu görevler verilmiştir:

1. Hükümetçe hazırlanacak iktisadi kanun ve tüzük tasarıları hakkında görüş bildirmek;

2. İktisadi mevzuatta gerekli görülen değişiklikleri gerekçeli teklifler halinde hükümete sunmak;

3. İktisadi ihtiyaçlarımız hakkında araştırmalar yapmak;

4. Dünyadaki değişik iktisat akımlarını inceleyerek bunların Türk ekonomisi ile ilgilerini ve Türkiye'ye etki derecelerini araştırmak. ${ }^{12}$

\section{Sanayi Alanına İlişkin Âli İktisat Meclisi Raporları}

Lozan Antlaşmasına göre yapılan mübadele işlemi ile Türkiye'den birçok tüccar, sanayici, sanatkâr, serbest meslek sahibi gibi nitelikli işgücünü oluşturan aileler gitmiştir. Yerlerine gelen nüfusun büyük çoğunluğunu ise tarımsal kökenli kişi ve aileler oluşturmaktadır. Kendi içinde dil ve din bakımından daha türdeş, içindeki etnik karşıtlıklar azaltılmış bir toplumsal yapı, iktisadi gelişme için daha elverişli bir ortam yaratacak ve ekonominin

\footnotetext{
${ }^{11}$ Ahmet Makal, Türkiye'de Tek Partili Dönemde Çalışma İlişkileri: 1920-1946, Ankara, İmge Kitabevi,1999, s.145.

12 Cazim Gürbüz, Atatürk Ekonomisi ve Beş Destan Adam, İstanbul, Asya Şafak Yayınları, 2009 , s.56.
} 
millileștirilmesi açısından uzun vadede olumlu olacaktır. Ancak bu girișim, kısa vadede Türk sanayisi üzerinde önemli problemler yaratmıştır. ${ }^{13}$

Liberal dönem olarak adlandırılabilecek dönemin devlet politikaları; ulusal burjuvazi yaratmaya yöneliktir. Buna bağlı olarak, Türkiye'nin hızlı bir şekilde kalkınabilmesi için motor niteliğinde olan sanayi sektörünün oluşturulmasını sağlayacak örgütler kurulmuş ve düzenlemeler yapılmıştır. İş Bankasının kurulması, Sanayi ve Maadin Bankası'nın, Devlet Sanayi Ofisi ile Sanayi Kredi Bankası'nın ve Sümerbank'ın kurulması bu kapsamda oluşturulmuş örgütler ve yapılmış düzenlemeler arasındadır. ${ }^{14}$ Yine çıkarılan kanunlardan biri olan Teşvik-i Sanayi Kanunu ile de Lozan Antlaşması'nın getirdiği koruyucu gümrük koyma engelinin getirdiği eksiklikler bir nebze de olsa giderilebilmiştir. ${ }^{15}$

Mustafa Kemal, Türkiye İktisat Kongresi'ni açış konuşmasında ekonomik kalkınma için sanayileşmenin zorunluluğunu belirterek, bu alanda yapılacak düzenlemelerin gerekliliğini şu sözlerle vurgulamıştır:

“...Fakat aynı zamanda sanayimizi de güzelleştirmek, geliştirmek zorundayız. Ĕger sanayi konusunda hoşgörülü olmaya devam edersek, endüstri ürünleri yönünden, yine diş ülkelere haraç vermek zorunda kalırtz." 16

1920'lerden süregelen ve sanayi sektörünü etkileyen ticaret açığı 1929 yılında ciddi bir dengesizlik halini almış, TL'nin yabancı paralar karşısındaki değer kaybı hızlanmıştır. Oluşan ödemeler dengesi açı̆̆ının kapatılması amacıyla ithal ikameci olanakların araştırılmasına ve sanayileşmenin hızlandırılmasına yönelik yeni öneriler getirmek üzere ÂİM'den (1929 Haziranında) “Türkiye'nin İktisadi Programı”nı hazırlaması istenmiştir. ÂİM'nin başlattığı bu program hazırlama işini Aralık ayında İktisat Vekili Şakir Kesebir ile birlikte İktisat Vekâleti üstlenmiştir. ${ }^{17}$ Böylece daha sonra "Şakir Kesebir Plânı" olarak anılan plân için İktisat Vekili Şakir Kesebir başkanlığında kurulan bir komisyon ${ }^{18}$ ülkenin çeşitli

${ }^{13}$ Erdinç Tokgöz, Türkiye'nin İktisadi Gelişme Tarihi (1924-2007), 8. Bası, Ankara, İmaj Yayınevi, 2007, s.48.

${ }^{14}$ Yalçın Küçük, Türkiye Üzerine Tezler: 1. Cilt, İstanbul, Salyangoz Yayınları, 2007, ss. 4259; Hâkimiyet-i Milliye, 21 Nisan 1933.

${ }^{15}$ Yalçın Küçük, Plânlama, Kalkınma ve Türkiye, 4. Basım, İstanbul, Tekin Yayınevi, 1975, s.241.

${ }_{16}$ Atatürk'ün Söylev ve Demeçleri, Ankara, Atatürk Araştırma Merkezi, 2006, ss. 466-478.

${ }^{17}$ Tezel, s. 214.

${ }^{18}$ Bu komisyon, İktisat Vekili Şakir Kesebir başkanlığında Bekir Raif, Selahattin Muhtar, Mehmet Vehbî, Niyaa Asım ve Nurullah Esat beylerden oluşmuştur. 
yerlerinde incelemeler yapmıştır. ${ }^{19} \mathrm{Bu}$ plân dünya iktisat buhranı nedeniyle uygulanamasa da Türkiye'deki ilk iktisadi program çalışması olması, 1938 planının temellerini oluşturması ve Birinci Sanayi Plânındaki gibi ithal ikameci yaklaşıma sahip birçok yatırımın kaynağını oluşturması bakımından önemlidir. ${ }^{20}$

Üç gruba ayrılan komisyon tarafından yapılan incelemeler sonucu “İktisadi Vaziyetimize Dair Rapor" hazırlanmış ve 1930 yılında milletvekillerine dağıtılmıştır. Rapora göre, ticaret açığının kapatılabilmesi için ya ihraç gelirlerini arttırmak, ya ithal harcamalarını kısmak, ya da bir yandan ihraç gelirlerini arttırırken bir yandan da ithalâtı azaltmak gerektiği sonucu ortaya çıkmıştır. ${ }^{21}$ Buna bağlı olarak, sanayileşmeyi hızlandırmak için tekstil gibi bazı belirli mallarda yoğun ithal ikamesine gidilmesine yönelik bir politika oluşmuştur. ${ }^{22}$ Genel olarak geçmiş dönemlere ait değerlendirmelerin ayrıntılı olarak ele alındığ 1 raporda, var olan uygulamalardan çok farklı yaklaşımlar ortaya konulmamıştır. Sanayileşme konusunda tatmin edici gelişmelerin sağlanmadığı bir ortamda rapor fazla dikkat çekmemiştir. 1930 yılında hazırlanan K. Müller, H. Schacht ve M. Charles Rist raporları da aynı arayış çabalarının birer örneğidir. K. Müller ve H. Schacht tarafindan, çevre ülke olarak nitelendirilen Türkiye, modernist bir bakış açısıyla değerlendirilmiştir. Ancak bu görüşleri kabul görmemiştir. $^{23}$

1930'lara gelindiğinde Türk ekonomisinin sorunu, mevcut üretim kapasitesinin tam kullanılamaması değil, yeni kapasite yaratmak ve verimliliği arttırmaktır. Az sayıda tarım ürünü dışında dışarıya satacak malı olmayan ve sanayi ürünlerinden en zaruri tüketim mallarını bile dışarıdan almak zorunda kalan bir ekonomi söz konusudur. Bu sorunlar ekonomide talep eksikliği ile ilgili olmadığından açık bütçe politikası izleyerek yeni talep yaratılması ve ekonominin canlandırılması beklenemez. Batı ülkeleri 1929 Bunalımından sonra koruyucu politikalarla ithalatı kısmaya,

\footnotetext{
19 Tarık Zafer Tunaya, Atatürk Döneminin Ekonomik ve Toplumsal Tarihiyle İlgili Sorunlar Sempozyumu içinde (14-16 Ocak 1977), İstanbul, İstanbul Yüksek İktisat ve Ticaret Mektebi Mezunları Derneği Yayını, s. 54.

20 Selim İlkin, Tekeli İlhan, Devletçilik Öncesi Sanayi Politikası Arayışları, Makine Mühendisleri Odası Sanayi Kongresi, 1976, s.3-4.

${ }^{21}$ Tezel, s. 215.

22 Selim İlkin, Tekeli İlhan, Devletçilik Öncesi Sanayi Politikası Arayışları, Makine Mühendisleri Odası Sanayi Kongresi, 1976, s.6.

${ }^{23}$ Uğur Korum, "1923-1929 Döneminde Türkiye’de Imalat Sanayii ve Sanayi Politikaları", A.Ü. SBF Maliye Enstitüsü ve Türkiye Ekonomi Kurumu (Haz.), Atatürk Dönemi Ekonomi Politikası ve Türkiye'nin Ekonomik Gelişmesi Semineri, Ankara, A.Ü. SBF Yayınları, 1982, ss. 63-78.
} 
devalüasyonla ihracatı artırmaya çalıșmışlar aynı zamanda ülke içinde de talep artırıcı para ve maliye politikaları uygulamışlardır. Böylece ülkelerindeki kapasite kullanım oranlarını artırmaya çalışmışlardır. Türkiye ise hem krizle mücadele hem de kalkınma hamlesini gerçekleştirmek amacıyla yeni kapasite yaratmak zorundadır. Bunun için, açık bütçe yoluna başvurulmamıs, döviz kontrolü, ithalat resimleri, kontenjan ve kliring uygulamalar ${ }^{24}$ ile ödemeler dengesi problemi aşılmaya çalış1lırken, ülke içinde finansman ihtiyacını karşılamak amaçlanmış ve etkin bir kredi organizasyonu ile bankacılık sektörünün güçlendirilmesine gidilmiştir. ${ }^{25} \mathrm{Bu}$ bağlamda, 5 Ocak 1933'te 9. devre toplantısını yapmak üzere toplanan ÂİM'nin birinci gündem maddesini Türkiye'de sanayinin nasıl kurulup geliştirileceği oluşturmuş, ülkenin hızlı bir iktisadi kalkınma gerçekleştirememesinin temel sebebi sermaye kıtlığına bağlanmıştır. Hükümet bu kıtllğ kurduğu bankalar ve devlet işletmeleri ile aşmaya çalışmış, bütçe olanakları ve başka bazı cebri tasarruf yöntemleri ile desteklemeye yönelmiştir. ÂİM'nin bu kurumlardan bazısına yönelik eleştirileri etkili olmuştur. Buna bağlı olarak da kurulması düşünülen Devlet Sanayi Ofisi (DSO) ve Türkiye Sanayi Kalkınma Bankası (TSKB) kanunlarında yapılan değişiklikle bu iki kurum yerine 3 Haziran 1933 tarih ve 2262 sayıll yasa ile Sümerbank kurulmuştur. ${ }^{26}$

ÂİM'nin 9 Ocak 1933 tarihli toplantısı sonucunda özel kesimin makine, yedek parça, gümrük resmi, arazi, bina ve kazanç vergileri vb. gibi konulardan muaf tutulması düşünülmüştür. Teşvik-i Sanayi Kanununda yerini bulan ÂİM tarafindan önerilmiş bu muafiyetler 15 y1l yürürlükte kalmak üzere yayınlanmış olmasına rağmen, Sanayi Kredi Bankası kanunu

24 Malını alanın malını alma ilkesine dayanan kliring sisteminde ithalat ihracata bağlandığından, ihracat teşvik edilmiş olur. Türkiye tarafından bütün ülkelerle kliring anlaşması yapılmaya çalışılmış ve ithalatta bu ülkelere öncelik tanınmıştır. Ayrıca ihraç malları standardize edilerek, ihracat desteklenmiştir. 10.06.1930 tarih ve 1705 sayılı kanunla hükümete tedbir alma yetkisi verilerek, ihraç edilen findık ve yumurtadan başlamak üzere kalite kontrolüne gidilmiştir. Önceleri çeşitli mercilerce sürdürülen bu iş, 1934'te kurulan Türkofis'e devredilmiştir. Ayrıntılı bilgi için bkz. Avni Zarakolu, "1929-30 Dünya Ekonomik Krizi Karşısında Türk Ekonomisi ve Alınan Krizle Mücadele Tedbirleri”, A.Ü. SBF Maliye Enstitüsü ve Türkiye Ekonomi Kurumu (Haz.), Atatürk Dönemi Ekonomi Politikasl ve Türkiye'nin Ekonomik Gelişmesi Semineri, Ankara: A.Ü. SBF Yayınları, 1982, s. 108.

${ }^{25}$ Avni Zarakolu, "1929-30 Dünya Ekonomik Krizi Karşısında Türk Ekonomisi ve Alınan Krizle Mücadele Tedbirleri”, A.Ü. SBF Maliye Enstitüsü ve Türkiye Ekonomi Kurumu (Haz.), Atatürk Dönemi Ekonomi Politikası ve Türkiye’nin Ekonomik Gelişmesi Semineri, Ankara: A.Ü. SBF Yayınları, 1982, s. 103.

${ }^{26}$ Âli İktisat Meclisi Raporları, Türkiye'de Sanayi Nasıl Tesis ve Inkişaf Edebilir?, Ankara, Başvekalet Müdevvenat Matbaas1, 1933, s.334-335; 2262 No'lu Sümerbank Kanunu (11 Haziran 1933 Tarih, 2424 say1l, T.C. Resmi Gazete). 
ile makine ve yedek parça muafiyeti kaldırılmıştır. Sanayi erbabı, kazanç vergileri muafiyetinde saptanmış oranda mecburî tasarrufa zorlanmış ve bu tasarruflar Kredi Bankasına ayrılarak kaydedilmiştir. ${ }^{27}$ Meclise ait aynı raporda ele alınan sanayinin kurulması için gerekli kredi konusunda "2064 numaralı kanunla oluşturulan Sanayi Kredi Bankası bu ihtiyacı karşılamaya uygun değildir" denilmiştir. Ardından Sanayi Bankasının 1slahı için Bankaya büyük bir itibar ve güven ve senede 1,5 milyon lira derecesinde bir kâr getiren fabrikaların Bankadan ayrılmaması ve Bankanın idare şeklinin halkın da iştirak edeceği bir anonim şirket haline getirilmesi gerektiği vurgulanmıştır. Meclisin bu çabaları sonucunda hazırlanan Sümerbank Kanun tasarısı kabul edilerek yasalaşmıştır.

Meclis sanayi faaliyetlerinin ilerlemesinde ucuz nakliyat ve yakacak madde temininin önemine değinmiştir. $\mathrm{Bu}$ konular Teşvik-i Sanayi Kanununda dikkate alınarak kanunun 10. maddesinde sanayiye ait makinelerle inşaat malzemesinin taşınmasında kara ve deniz nakliye tarifeleri üzerinden $\% 30$ indirim yapılacağ ${ }_{1}$ belirtilmiştir. ${ }^{28}$ Ayrıca, sanayi müesseselerinde maliyeti düşürme konusunda rasyonel çalışma tarzının bilinmesinin önemli çarelerden biri olduğu ifade edilmiştir. Meclisin aynı tarihteki raporunda devletin sanayicilik yapıp yapmamas1 konusunda, devletin kendi veya iştiraki ile oluşacak sanayi hareketlerinde (KİT'lerde), halkın kuruluş sermayelerine katılması desteklenmeli ve teşebbüs kökleşip kâr etmeye başladığ 1 zaman tesisler ilk firsatta özel girişime ve halka mal edilmeli denmiştir. ${ }^{29}$

Atatürk, TBMM'nin üçüncü toplanma y1lı olan 1 Mart 1922'de yaptı̆̆ açış konuşmasında madenlerin işletilebilmesinin gerekliliklerinden bahsetmiştir. $\mathrm{Bu}$ gerekliliklere göre, topraklarımız altında kullanılmadan duran maden cevherleri kısa sürede işletilerek millet yararına sunulmalıdır. $\mathrm{Bu}$ da genel yararı doğrudan doğruya ilgilendirecek kurumlar ve iktisadi girişimlerin ülkenin malî gücü ve teknolojik imkânları elverdiğince devletleştirilmesi ile mümkündür. Bu bağlamda, sadece iktisadî yararlanma amacı ile gerek madenlerimizde gerekse de diğer iktisadî konularda, çalışmak isteyen sermeye sahiplerine hükümetçe gerekli kolaylıklar sağlanmalıdır. Türkiye Cumhuriyeti ancak bu suretle ülkenin yeraltındaki

\footnotetext{
${ }^{27}$ Kazım Karabekir, Iktisat Esaslarımız, (Yay. Haz. Orhan Hülagü ve Ömer Özalp), Emre Yayınları, İstanbul, 2001, s.86-92.

28 Âli İktisat Meclisi Raporları, Türkiye'de Sanayi Nasıl Tesis ve İnkişaf Edebilir?, Ankara, Başvekalet Müdevvenat Matbaası, 1933, s. 337-338.

${ }_{29}$ Âli İktisat Meclisi Raporları, Türkiye’de Sanayi Nasıl Tesis ve Inkişaf Edebilir?, Ankara, Başvekâlet Müdevvenat Matbaası, 1933, s. 333-334.
} 
maden zenginliklerini kısa zamanda arttırabilir ve halkın yararına işletebilir. ${ }^{30}$

ÂİM'nin 1933 tarihinde yayınlanan "Madenlerimizden En İyi Surette İstifade Şekli Nedir?" başlıklı raporunda da, maden sanayinin kurulabilmesi için gerekli koşullar şu şekilde sıralanmıştır. Rapora göre, ülkedeki madenlerin milli iktisada uygun yürütülebilmesi için maden cevherleri işletilmelidir. Uzun süre ve büyük miktarlarda üretim yapmaya uygun görülen cevher yataklarının işletilmesi için yapılacak tesis öncesi büyük miktarda harcama gerektiren ve risk taşıyan önemli araştırmalar yapılmalıdır. Bu suretle kurulan bir madenin devamlı ve yararlı bir iş olabilmesi için tesisatının tekniğe uygun kurulması ve teknik gelişmelerin takibi gereklidir. Madenler devletçe halktan bir kesimin yüksek oranda kazanç elde ettiği, ülke için yararlı üretim kaynakları olarak kabul edilmeli ve bu konuda gereken yasal düzenlemeler yapılmalıdır. ${ }^{31}$

\section{Ticaret Alanına İlişkin Âli İktisat Meclisi Raporları}

1920'lerde, emisyon bankası olarak çalışan ve 1925 'te çalışma yetkisi sona eren Osmanlı Bankası yerine emisyon hacmini arttıracak bir merkez bankası kurulamadığından kalkınma finanse edilememiştir. ${ }^{32} \mathrm{Bu}$ sebeple kredi hacminin artması için çok sayıda yabancı banka ile bu banka fonlarının yurtiçine çekilmesi şarttı. İngiliz Sterlini'ne bağlanan TL diş ticaret sürekli açık verdiği için değer kaybediyordu. Yani; ekonominin zayıf ve dışa bağımlı yapısı başta para-kambiyo sisteminden kaynaklanmıştır.

1929'da ABD'deki Büyük Buhran nedeniyle dünyada oluşan olumsuz ekonomik konjonktür Türkiye'nin kendi içindeki olumsuz koşullarla birleşmiştir. 1929 y1lında Lozan'ın getirdiği gümrük tarifeleriyle ilgili kısıtlamaların kalkmasıyla Türkiye bağımsız bir dış ticaret politikası oluşturabilecekti. Ancak gümrük vergilerinin yükselecek olması dolayısıyla tüccarların stoklamak amaciyla fazla mal satın alması ithalat patlamasına yol açmıştır. Ayrıca kötü ürün yılı yüzünden tahıl ithalatı artmıştır. Bunlara Osmanlı borçlarının ilk taksidinin ödenecek olması da eklenmiştir. ${ }^{33}$ Döviz yükümlülüklerinin bu kadar arttığı bir ortamda Büyük Buhranın tarım

30 Vladimir Danilov, "Mustafa Kemal Atatürk ve Türkiye Cumhuriyeti Bağımsız Gelişmesinin İlkeleri”, Uluslar arası Atatürk Konferansı Tebliğleri, c.1, İstanbul, Boğaziçi Üniversitesi Yayınları, 10-11 Kasım 1980, s. 114.

${ }^{31}$ Âli İktisat Meclisi Raporları, Madenlerimizden En İyi Surette İstifade Şekli Nedir?, Ankara, Başvekâlet Müdevvenat Matbaası, 1933, s. 9-11.

32 Fikret Başkaya, Devletçilikten 24 Ocak Kararlarına, Türkiye Ekonomisinde İki Bunalım Dönemi, Maki Basın Yayın, Ankara, 2004, s.100.

${ }^{33}$ Korkut Boratav, Türkiye İktisat Tarihi 1908-1985, İstanbul, Gerçek Yayınevi, 1989, s.36. 
ürünleri fiyatlarını düşürmesi dolayısıyla o döneme kadar görülmemiş bir dış ticaret açığ 1 oluşmuş ve kambiyo krizi patlamıştır. ${ }^{34}$ Türk Lirasındaki hızlı değer düşüşü, kısa vadeli dış borcu bulunanların iflasına yol açmıştır. Ancak bu durum hükümetçe uluslararası bir bunalımdan çok spekülatif (açıktan) ithalata bağlanmıştır. $\mathrm{Bu}$ sebeple de halkı tasarrufa ve yerli malları kullanmaya yöneltmek için 1929'da Milli İktisat ve Tasarruf Cemiyeti kurulmuştur. Bunu takiben ilkin Menkul Kiymetler ve Kambiyo Borsaları Kanunu ve bunun para değerinin korunmasında yetersiz görülmesiyle de 1930 tarihli ve 1567 sayılı Türk Parasının Kıymetini Koruma Hakkında Kanun çıkarılmıştır. Merkez Bankası kuruluncaya kadar kambiyo alımsatımını idare etmek ve spekülasyona engel olmak için milli ve yabancı bankaların katılımı ile Bankalar Konsorsiyumu kurulmuştur. Alınan tedbirlerin ve Bankalar Konsorsiyumunun önemli katkıları ile de 1930'un üçüncü ayından sonra Kambiyo Borsalarında istikrar sağlanmıştır. ${ }^{35}$ Ancak Türkiye'nin kendi parasına hâkim olmasını sağlayan ve para-kambiyo rejimini tamamen değiştiren olay, 1930'da Merkez Bankası'nın kurulmasıdır. Merkez Bankası'nın kurulmasıyla birlikte, serbest kambiyo rejimi sona erdirilmiştir. Dış ticaret kotalara bağlanmış ve kliring anlaşmaları, yapılmıştır. Bunun sonucunda Türkiye, Buhran sırasında dünyanın bağımsız kesiminin izlediği yolu izleyerek faiz haddini, kambiyo düzenini ve dış ticaretini denetim altına alabilmiştir. ${ }^{36}$

Ticaret alanına ilişkin çeşitli uygulamalar başlatılmasına rağmen, 19231929 arası dönemde ticaret dengesinin sağlanamaması nedeniyle açıklar oluşmuş ve ticaret alanında ödeme dengesini koruyabilmek için aktife ihtiyaç duyulmuştur. Bunu kural kabul eden CHP, programının 12. maddesi ile ödeme dengemizi düzenleme ve bu yönden ithalat-ihracatımızda ahenk oluşturma sorumluluğunu üstlenmiştir. Aynı yıllar içinde ticaret dengesinde ihracat, bunun karşılığ1 olan ithalâta oranla daima düşük kalmış, yani dış ticaret açık vermiştir. Bu konuyla ilgili olarak, ÂİM'nin 1926 yılının tediye muvazenesindeki pasif bakiye'yi 44.917.000 lira olarak tespit etmesi örnek gösterilebilir. Uluslar arası ödeme dengesinin tespit edilmeye çalışıldığ 1 henüz mükemmelliğe ulaşmamış olan önceki yıllara ait bu çalışmaya göre Türkiye, dış borçları, mali yükümlülükleri, sigorta primleri, yabancı ülkelerdeki temsilcileri ve talebeleri, deniz nakliyatından doğan verecekleri

\footnotetext{
${ }^{34}$ Gülten Kazgan, Tanzimat'tan 21. Yüzyıla Türkiye Ekonomisi Birinci Küreselleşmeden İkinci Küreselleşmeye, İstanbul, İstanbul Bilgi Üniversitesi Yayınları, 2002, s. 63-64.

${ }^{35}$ İlhan Tekeli ve Selim İlkin, 1929 Dünya Buhranında Iktisadi Politika Arayışları, Ankara, ODTÜ İdari Bilimler Fakültesi Yayınları: 30, Türkiye Belgesel İktisat Tarihi Serisi: 2, 1983, s. 80-82.

${ }^{36}$ Kazgan, a.g.e., s. 65; 1715 No'lu Türkiye Cumhuriyeti Merkez Bankası Kanunu (30 Haziran 1930 Tarih, 1533 say1l, T.C. Resmi Gazete).
} 
gibi masrafları ancak yabancı döviz şeklindeki bir aktifle karşılayabilirdi. ${ }^{37}$ $\mathrm{Bu}$ bağlamda, Osmanlı döneminden kalma Pasaport Kanununda yapılan 1934 yılındaki değişiklikle pasaport harçlarının 50 Kuruş'tan 25 TL'ye yükseltilmesi ile dış seyahatlerin güçleştirilerek azaltılması döviz sıkıntısını hafifletmek amacıyla yapılmış düzenlemeler arasında sıralanabilir. ${ }^{38}$

ÂİM'nin, program hazırlama konusundaki temel yaklaşımı "İktisadi Vaziyetimize Dair" başlıklı raporun maddelerine de yansımıştır. Buna göre, memleketimizde yetişen veya yetişebilecek türden ürünler için tarife engelleri getirilmeli ve bu amaçla ihtiyaç duyduğumuz ürünler memleket dâhilinde yetiştirilmelidir. Bunun mümkün olmadığı ve ithal etmek zorunda olduğumuz ürünlere karşı da aynı değerde ihracatta bulunulmalıdır. $\mathrm{Bu}$ bağlamda, rapor o yılların en öncelikli konusu olan para değeriyle yakından ilgilidir. 1929 yılı, gümrük tarifelerindeki kısıtlamaların kalkması dolayısıyla cari açığın bir önceki yıla göre iki katı artması ile bir para bunalımına sahne olmuştur. ${ }^{39}$ Aynı yıl (1930) Türk Parasının Kıymetini Koruma Kanununun da çıkarıldığı göz önüne alındığında raporda öncelikli olarak amaçlananın dış ticaret açığı vermemek ve böylece para değerindeki değişmeleri önlenmek olduğu sonucu çıkarsanabilir. ${ }^{40} \mathrm{Bu}$ rapor çalışması, uzun vadeli ve makro bir yaklaşım taşımadığ 1 için dış ticaret dengesi ne ekonominin bütünü ne de sektörsel olarak ele alınmamış, her bir mal düzeyinde inceleme yapılmıştır. Ayrıca programın ne kadar süreyi kapsadığı ve alınacak tedbirlerin kaç yılda dış ödemeler dengesini sağlayacağı belirsizdir. Program özellikle ithalat içinde büyük yer tutan zorunlu ihtiyaç maddelerinde kendine yeterli hale gelmeyi ve bunu sağlamak için tarifelerin yükseltilmesi gerektiğini vurgulayarak ithal ikameci bir yaklaşıma sahiptir. Ancak dış ticaret dengesini sağlarken yalnızca ithalatın kısıtlanmasına karşı çıkmıştır. Bunun yerine ticaret hacmini daraltmadan ve muhtemelen dışa bağımlılığın yüksek ve üretim kabiliyeti gelişmemiş bir ülke olunmasını da dikkate alarak ihracat artışı sağlamayı gözetir. ${ }^{41} \mathrm{Bu}$ amaçla, gümrüklerle ilgili olarak TLPound dalgalanma aralığının belirlenmesi ve devletin güvenliği, kamu

\footnotetext{
${ }^{37}$ Haldun Derin, Türkiye'de Devletçilik, İstanbul, İstanbul Yayınevi, 1940, s. 113; 1926 yılı Âli İktisat Meclisi ödeme dengesindeki pasif bakiye miktarlarına ilişkin ayrıntılı bilgi için bkz. Ek.1.

${ }^{38}$ Cemil Koçak, Geçmişimiz İtinayla Temizlenir, 5. Baskı, İstanbul, İletişim Yayınları, 2010, s. 205 .

39 Korkut Boratav, “Büyük Dünya Bunalımı İçinde Türkiye’nin Sanayileşme ve Gelişme Sorunları: 1929-1939”, Tarihsel Gelişimi İçinde Türkiye Sanayi, Ankara, TMMOB Makine Mühendisleri Odas1 Yayın No: 106/1, 1977, s. 8.

${ }_{40}$ İlker Parası, Türkiye Ekonomisi, Bursa, Ezgi Kitabevi Yayınları, 2003, s.59.

${ }^{41}$ Kesebir, a.g.r., s. 171.
} 
tekelleri kurma ve destekleme amaçları dışında Türkiye'nin ithalât ya da ihracatta ambargo uygulamaması kararlaştırılmıştır. ${ }^{42}$

Ticarette uygulanan gümrük siyasetine ilişkin ÂİM raporlarındaki verilere göre, uluslar arası ekonomik ilişkilerin bir unsuru olan gümrük siyasetinin temel amacı öncelikle ülkenin ekonomik ilerlemesini sağlamaktır. Bu amaç doğrultusunda serbest mübadele-ticaret ve himaye sistemi ile yürütülen gümrük siyaseti bir iktisat meselesi olduğu kadar devletin genel siyaseti ile de ilişkili bir meseledir. Devletlerin siyasi varlıkları gücünü iktisadî bünyeden aldığı için de sadece dış rekabetin tehdit ettiği iktisadî faaliyet alanlarının değil, genel iktisadî durumun gerektirdiği bütün alanların sistematik bir devlet himayesine ihtiyac1 vardır. $\mathrm{Bu}$ bağlamda, bir ziraat ülkesi olan ve ihraç ürünleri tütün, meyve-sebze, yapağ1, tiftik, hall, pamuk, palamut ve maden cevherlerinden; ithal ürünleri ise pamuk mamulât1, hububat ve ürünleri, yün iplik ve ürünleri ve madeni ürünlerden oluşan Türkiye'nin öncelikle ithalâtını azaltıp ihracatını da arttırması gerekmektedir. ${ }^{43}$ İstanbul Ticaret Odas1, hazineye gelir sağlamayı amaçlayan bu esas doğrultusunda bir gümrük tarifesi tespiti projesi düzenlemiştir. Hazırlanan projede her nevi hayvanat, alet-edevat, üretim ve nakliye araçlarının, taşınması gereken ziraat ve sanayiye yönelik eşyanın tam muafiyete tabi tutulması kabul edilmiştir. Ayrıca, ürünlerin himayesinde yararlılık ölçütü temel alınmıştır. ${ }^{44}$

Meclis'in, hazır olduğu halde ancak 1929 yılında uygulanmaya başlanacak $^{45}$ yeni gümrük tarifesinin hazırlanması sırasında savunduğu görüşe göre, gümrük tarifeleri ve diş ticaret politikası söz konusu olduğunda akla gelen ilk önlem yerli sanayiyi dış rekabetin etkilerinden yalıtarak korumaktır. ${ }^{46}$ Gümrük tarifelerinin kabulü sırasında ülkenin zirai üretiminde büyük bir artış olduğu belirlenmiş; bu artışın da özellikle buğday üretiminde olduğu ve bunun buğdayın dışarıdan gelen buğdaya karşı korunması ile

${ }^{42}$ Korum, s.65.

43 Âli İktisat Meclisi Raporları,1928 İkinci İçtima Devresi, Gümrük Siyasetimizin Esasları, Hâkimiyeti Milliye Matbaas1, 1929, s.1-5.

${ }^{44}$ Âli İktisat Meclisi Raporları (1 Mart-19 Mart 1928), 1928 Birinci İçtima Devresi, Gümrük Tarifelerinde Kabul ve Takip Edilecek Esaslar, Türk Ocakları Merkez Heyeti Matbaası, 1928, s.2; Bkz. Ek.2.

${ }^{45}$ Necdet Serin, Türkiye'nin Sanayileşmesi, Ankara Üniversitesi Siyasal Bilgiler Fakültesi Yayınları No. 167-149, Ankara, Sevinç Matbaası, 1963, s. 106.

46 Âli İktisat Meclisi Raporları, 1928 İkinci İçtima Devresi, Gümrük Siyasetimizin Esasları, Hâkimiyeti Milliye Matbaası, 1929, s.19 
ilişkisi bulunduğu tespit edilmiştir. ${ }^{47}$ Sanayi alanında ise ülkede mevcut sanayi müesseselerine her y1l yenilerinin eklendiği ve çıkarılan Teşvik-i Sanayi kanununun bu durumla ilgili olduğu görülmüsstür. Bununla birlikte bugün sanayi ürünlerinin ticaretinde uygulanan gümrük resmi diğer ülkeler ve özellikle de komşu devletlerin gümrük resimlerine oranla daha 1lımlıdır. ${ }^{48}$

İthalatın azaltılması konusunda devlete de görev yüklenmiştir. Özellikle dış ticaretimizde büyük paya sahip ve hammaddesi memleket dâhilinde bulunan sektörlerde ithalat yerine yerli üretimi destekleyen bir program oluşturulması gerektiği belirtilmiştir. Ancak devlete sanayi üretimine yönelik devletçi bir görev yüklenmemiş, yalnızca bir üretim programı yapması görevi verilmiştir. ${ }^{49}$ Sanayileşmek için milli sermayenin henüz yeterli olmadığını kabul eden Kesebir, bunun çözümünü devletin demir, kömür, kimyevi gübre gibi önem taşıyan sanayi dallarına iştirak etmesinde ve yardımında, diğer alanlarda ise devletin yabancı sermaye girişini teşvik etmesinde görmüştür. Plan bu yaklaşımıyla iktisat politikasında yapısal bir dönüşüm önermez, aksine liberal bir yaklaşımla, özel sektör eliyle kalkınma çabasının devamını savunur. Aynı liberal yaklaşım ihracat artışı için önerilerinde mutlak üstünlükler teorisine atıf yapar. Teoriye göre, "kabiliyetimizin en müsait olduğu şubelerde" uzmanlaşmamız gereklidir. Ayrıca ihracat artışı için devlet özel sektörü teşvik etmeli ve kaynak aktarmalıdır. Bu durum sermaye birikimi üzerinde de etkili olacaktır. ${ }^{50}$

Program, özel sektöre dayanması ve ticaretin canlandırılmasının ön plana çıkarılması ile daha sonra ele alınacak olan devletçi yaklaşımdan oldukça farklı olmakla birlikte, Sanayi Planında yer alacak birçok projeye de yer vermiştir. Selüloz, kâğıt, suni ipek fabrikalarının kurulması pamuk üretiminin arttırılıp dokuma fabrikaları kurulması ve böylece büyük bir ithalat kaleminde tasarruf sağlanması, Kütahya çini, sünger ve gülyağı fabrikası, demir-çelik ve kimya sanayinin kurulması gibi projeleriyle BBYSP ile örtüşen noktalara sahiptir. ${ }^{51} \mathrm{Bu}$ örtüşmenin nedeni, raporda tavuktan hayvan gübresine, köseleden pamuk ve pamuklu dokumaya, transit ticaretten serbest bölgelere, madenlere kadar diş ticarete konu mallar ve ilgili sektörlerin tümünü içeren çalışmalar yapılmasıdır. Ayrıca, alınabilecek

\footnotetext{
47 Âli İktisat Meclisi Raporları (1 Mart-19 Mart 1928), 1928 Birinci İçtima Devresi, Gümrük Tarifelerinde Kabul ve Takip Edilecek Esaslar, Türk Ocakları Merkez Heyeti Matbaası, 1928, s.3; Bkz. Ek.3.

${ }^{48}$ Selim İlkin, İlhan Tekeli, "Cumhuriyetin İlk Yıllarında Sanayinin Korunması Sorunu ve Ticaret Sermayesinin Tavrı", Makine Mühendisleri Odası Sanayi Kongresi, 1976, s.15.

${ }^{49}$ Kesebir, a.g.r., s.166-168; İlhan Tekeli ve İlkin Selim, a.g.m., s.104.

${ }^{50}$ Kesebir, a.g.r., s.171-172.

${ }^{51}$ İlhan Tekeli ve İlkin Selim, a.g.m., s.109-110.
} 
tedbirlere yer vererek sanayi, ithalat ve ihracatla ilgili temel yaklaşımlar önermesi de etkili olmuştur. Kapsamı bu kadar geniş tutulunca doğal olarak BBYSP ile örtüşen birçok nokta ortaya çıkmıştır.

ÂİM'nin Türkiye'nin 1930'lu yıllardaki dış ödemeler dengesiyle ilgili “Türkiye'nin Tediye Muvazenesi” başlıklı raporunda ${ }^{52}$ gümrük istatistiklerinden elde edilen ihracat rakamlarının, yanlış beyan ve ihracattaki gümrük kaçakçılığından kaynaklanan veri hataları düzeltilmiş; ithalâta ilişkin gümrük istatistikleri verilerine de eksik olan hükümet ithalâtı, kaçak ithalât eklenerek yanlış beyanlara ilişkin düzeltmeler yapılmıştır. Ödemeler dengesinin "külçe halinde altın ve nukut ve evrakı nakdiye" akımlarında ise altın ihracı yasaktır, ancak altın kaçakçılığı sürmektedir. ${ }^{53}$

Ticaret konusunda büyük önem taşıan liman hizmetlerinin geliştirilmesi ile ilgili ÂİM raporunda ise limanlardaki ilerlemenin emniyetin varlığına, gümrükteki işlerin hızla ve kolaylıkla ve formalitelerden bağımsız bir şekilde ve ucuz yapılmasına bağlı olduğu belirtilmiştir. ${ }^{54}$

\section{Sonuç}

Bir danışma organı niteliğinde kurulan ÂİM, getirdiği önerilerle Sümerbank'ın kurulmasında, Türkiye'de planlama çalışmalarının başlatılmasında öncü olmuştur. İthal ikameci politikalara da zemin hazırlamıştır. Bununla birlikte, danışma organı niteliğini tam olarak yerine getiremeyen Meclis, ticaret sermayesine olan yakınlı̆̆ nedeniyle daha çok bu grubun sözcüsü gibi çalışmıştır. Bu durum, 24 üyeden oluşan Meclis'in seçimlerle gelen üyeleri arasında tüccar grubunun baskın olmasıly açıklanabilir. Buna bağlı olarak, Mecliste sanayinin korunmasına yönelik bir gümrük politikası ilke olarak kabul edilmiş olmasına rağmen bu ilkenin uygulanması konusunda tüccar grubunun ileri sürdügü koruyucu gümrük politikasını tümüyle saptırıcı nitelikler taşıyan bir politika izlenmesi gibi çelişkili birtakım durumlar oluşmuştur.

Tüccar sermayesinin ve özellikle de büyük ithalatçıların çıkarlarını ön plânda tutan ÂİM, sanayinin korunmadan da gelişebileceğini savunmuştur. Bunun dışında, gümrük tarifelerinin tespitinde ithalatçıların yüksek oranda kâr elde edebilmelerini sağlayan taraflı bir politika izlemiştir. Sonuç olarak

\footnotetext{
52 Türkiye'nin 1930'lu yıllardaki dış ödemeler dengesi aktifi ve pasifi bilgilerinin ayrıntıları için bkz. Ek. 4 ve Ek.5.

${ }^{53}$ Selim İlkin ve İlhan Tekeli, Uygulamaya Geçerken Türkiye'de Devletçiliğin Oluşumu, Ankara Ortadoğu Teknik Üniversitesi, İdari İlimler Fakültesi Yayınları, 1982, ss. 41-46.

54 Âli İktisat Meclisi Raporları, Türkiye’nin Liman Hizmetleri ve Limanlarımızın İnkişafinı Temin Edecek Tedbirlere Dair Teklifler, Ankara, Başvekâlet Müdevvenat Matbaası, 1932, s.33-35.
} 
politik iktidarı etkileyen veya elinde tutan değişik sermaye kesimleri arasında daha yüksek kâr elde etmeye yönelik süren çıkar çatışmaları Âli İktisat Meclisine de yansımıştır. Ülkenin ticaret ve sanayi alanında ilerlemesine yapacağı araştırmalarla yön verecek olan Meclis'in hazırladığ1 raporlar da bu durumdan etkilenmiştir. Öte yandan, Meclis 1929 Haziranında İktisat Vekili Şakir Kesebir'in başkanlığında hazırlanan İktisat Programı ile Türkiye'deki ilk iktisat programı örneğinin oluşturulmasında ve daha sonraki dönemlerde hazırladığı 1 raporlarla (1933) KİT'lerin kurulmasında ${ }^{55}$ önemli bir rol oynamıştır.

\section{KAYNAKLAR}

Âli İktisat Meclisi Raporları (1 Mart-19 Mart 1928), 1928 Birinci İçtima Devresi, Gümrük Tarifelerinde Kabul ve Takip Edilecek Esaslar, Türk Ocakları Merkez Heyeti Matbaas1, 1928.

Âli İktisat Meclisi Raporları, 1928 İkinci İçtima Devresi, Gümrük Siyasetimizin Esaslarl, Hâkimiyeti Milliye Matbaası, 1929.

Âli İktisat Meclisi Raporları, Madenlerimizden En İyi Surette İstifade Şekli Nedir?, Ankara, Başvekâlet Müdevvenat Matbaası, 1933.

Âli İktisat Meclisi Raporları, Türkiye'de Sanayi Nasıl Tesis ve Inkişaf Edebilir?, Ankara, Başvekalet Müdevvenat Matbaası, 1933.

Başkaya, Fikret, Devletçilikten 24 Ocak Kararlarına, Türkiye Ekonomisinde İki Bunalım Dönemi, Maki Basın Yayın, Ankara, 2004.

Boratav, Korkut, "Büyük Dünya Bunalımı İçinde Türkiye'nin Sanayileşme ve Gelişme Sorunları: 1929-1939”, Tarihsel Gelişimi İçinde Türkiye Sanayi, Ankara, TMMOB Makine Mühendisleri Odası Yayın No: 106/1, 1977.

Boratav, Korkut, Türkiye İktisat Tarihi 1908-1985, İstanbul, Gerçek Yayınevi, 1989.

Boratav, Korkut, Türkiye'de Devletçilik, 2. Baskı, Ankara, İmge Kitabevi, 2006.

Danilov, Vladimir, "Mustafa Kemal Atatürk ve Türkiye Cumhuriyeti Bağımsız Gelişmesinin İlkeleri", Uluslar arası Atatürk Konferansı Tebliğleri, c.1, İstanbul, Boğaziçi Üniversitesi Yayınları, 10-11 Kasım 1980.

Derin, Haldun, Türkiye'de Devletçilik, İstanbul, İstanbul Yayınevi, 1940.

Durdu, Mehmet Burak, "Camilla Jaquart'ın Raporuna Göre Atatürk Döneminde Türk Ekonomisi”, Kastamonu Eğitim Dergisi, C. 16, No:1, ( Mart 2008).

Gürbüz, Cazim, Atatürk Ekonomisi ve Beş Destan Adam, İstanbul, Asya Şafak Yayınları, 2009.

${ }^{55}$ Devlet Sanayi Ofisi (1932) ve Sümerbank (1933) kurulan en önemli KíT’ler arasındadır. 
Hâkimiyet-i Milliye, 21 Nisan 1933

İlkin, Selim ve İlhan Tekeli, "Cumhuriyetin İlk Yıllarında Sanayinin Korunması Sorunu ve Ticaret Sermayesinin Tavrı", Makine Mühendisleri Odası Sanayi Kongresi, 1976.

İlkin, Selim ve İlhan Tekeli, Devletçilik Öncesi Sanayi Politikası Arayışları, Makine Mühendisleri Odası Sanayi Kongresi, 1976.

İnan, Afet, İmir Iktisat Kongresi (17 Şubat-4 Mart 1923), Ankara, TTK Basımevi, 1989.

Karabekir, Kazım, Iktisat Esaslarımız, (Yay. Haz. Orhan Hülagü ve Ömer Özalp), Emre Yayınları, İstanbul, 2001.

Kazgan, Gülten, Tanzimat'tan 21. Yüzylla Türkiye Ekonomisi Birinci Küreselleşmeden İkinci Küreselleşmeye, İstanbul, İstanbul Bilgi Üniversitesi Yayınlar1, 2002.

Kesebir, Şakir, İktisadi Vaziyetimize Dair Rapor, Ankara, TBMM Matbaası, 1930.

Koçak, Cemil, Geçmişimiz İtinayla Temizlenir, 5. Baskı, İstanbul, İletişim Yayınları, 2010.

Korum, Uğur, “1923-1929 Döneminde Türkiye'de İmalat Sanayi ve Sanayi Politikaları”, A.Ü. SBF Maliye Enstitüsü ve Türkiye Ekonomi Kurumu (Haz.), Atatürk Dönemi Ekonomi Politikası ve Türkiye’nin Ekonomik Gelişmesi Semineri. Ankara, A.Ü. SBF Yayınları, 1982.

Kuruç, Bilsay, Belgelerle Türkiye İktisat Politikast (1929-1932), c.1, Ankara, Ankara Üniversitesi Siyasal Bilgiler Fakültesi Yayınları, 1988.

Küçük, Yalçın, Plânlama, Kalkınma ve Türkiye, 4. Basım, İstanbul, Tekin Yayınevi, 1975.

Küçük, Yalçın, Türkiye Üzerine Tezler: 1. Cilt, İstanbul, Salyangoz Yayınları, 2007.

Makal, Ahmet, Türkiye’de Tek Partili Dönemde Çalışma İlişkileri: 1920-1946, Ankara, İmge Kitabevi,1999.

Parasız, İlker, Türkiye Ekonomisi, Bursa, Ezgi Kitabevi Yayınları, 2003.

Serin, Necdet, Türkiye’nin Sanayileşmesi, Ankara Üniversitesi Siyasal Bilgiler Fakültesi Yayınları No. 167-149, Ankara, Sevinç Matbaası, 1963.

Sevim, Ali(Haz.), Atatürk'ün Söylev ve Demeçleri, Ankara, Atatürk Araştırma Merkezi, 2006.

Tecer, Meral, “Atatürk Döneminde (1923-1938) Ekonomik Örgütlenme”, Amme İdaresi Dergisi, Cilt. 39, sayı 4, Aralık 2006. 
Tekeli, İlhan ve Selim İlkin, 1929 Dünya Buhranında İktisadi Politika Arayışları, Ankara, ODTÜ İdari Bilimler Fakültesi Yayınları: 30, Türkiye Belgesel İktisat Tarihi Serisi: 2, 1983.

Tezel, Yahya Sezai, Cumhuriyet Döneminin İktisadi Tarihi (1923-1950), 3. Baskı, İstanbul, Yurt Yayınları, 1994.

Tokgöz, Erdinç, Türkiye’nin İktisadi Gelişme Tarihi (1924-2007), 8. Bası, Ankara, İmaj Yayınevi, 2007.

Tunaya, Tarkk Zafer, Atatürk Döneminin Ekonomik ve Toplumsal Tarihiyle Ilgili Sorunlar Sempozyumu içinde (14-16 Ocak 1977), İstanbul, İstanbul Yüksek İktisat ve Ticaret Mektebi Mezunları Derneği Yayını, 1977.

Ülken, Yüksel, Atatürk ve İktisat, Ankara, Türkiye İş Bankası Kültür Yayınları, 1981.

Zarakolu, Avni, "1929-30 Dünya Ekonomik Krizi Karşısında Türk Ekonomisi ve Alınan Krizle Mücadele Tedbirleri”, A.Ü. SBF Maliye Enstitüsü ve Türkiye Ekonomi Kurumu (Haz.), Atatürk Dönemi Ekonomi Politikası ve Türkiye'nin Ekonomik Gelişmesi Semineri, Ankara: A.Ü. SBF Yayınları, 1982. 


\section{EKLER}

EK.1.

Âli İktisat Meclisi'nin 1926 Yılı Tediye Muvazenesindeki Pasif Bakiye'ye İlişkin Tespitini Gösteren Tablo

\begin{tabular}{|c|c|c|}
\hline & AKTİF & PASİF \\
\hline Emtia & 208.973 .000 & 259.700 .000 \\
İhracat: 205.073.000 & & \\
Gemilere kömür ve & & \\
kumanya: 3.900.000 & & \\
Ticari hizmetler & 7.320 .000 & 261.000 \\
Sigorta & 2.500 .000 & 5.000 .000 \\
Faiz ve temettü & 700.000 & 8.336 .000 \\
Turizm, muhaceret & 4.549 .000 & 7.232 .000 \\
Devletçe yapılan & 5.270 .000 & 3.050 .000 \\
muameleler & 9.350 .000 & --------- \\
Sermaye hareketi & 44.917 .000 & --------- \\
Bakiye & & \\
& & 283.579 .000 \\
\hline
\end{tabular}

Kaynak: Derin, s.114 
EK.2.

Âli İktisat Meclisi Raporları

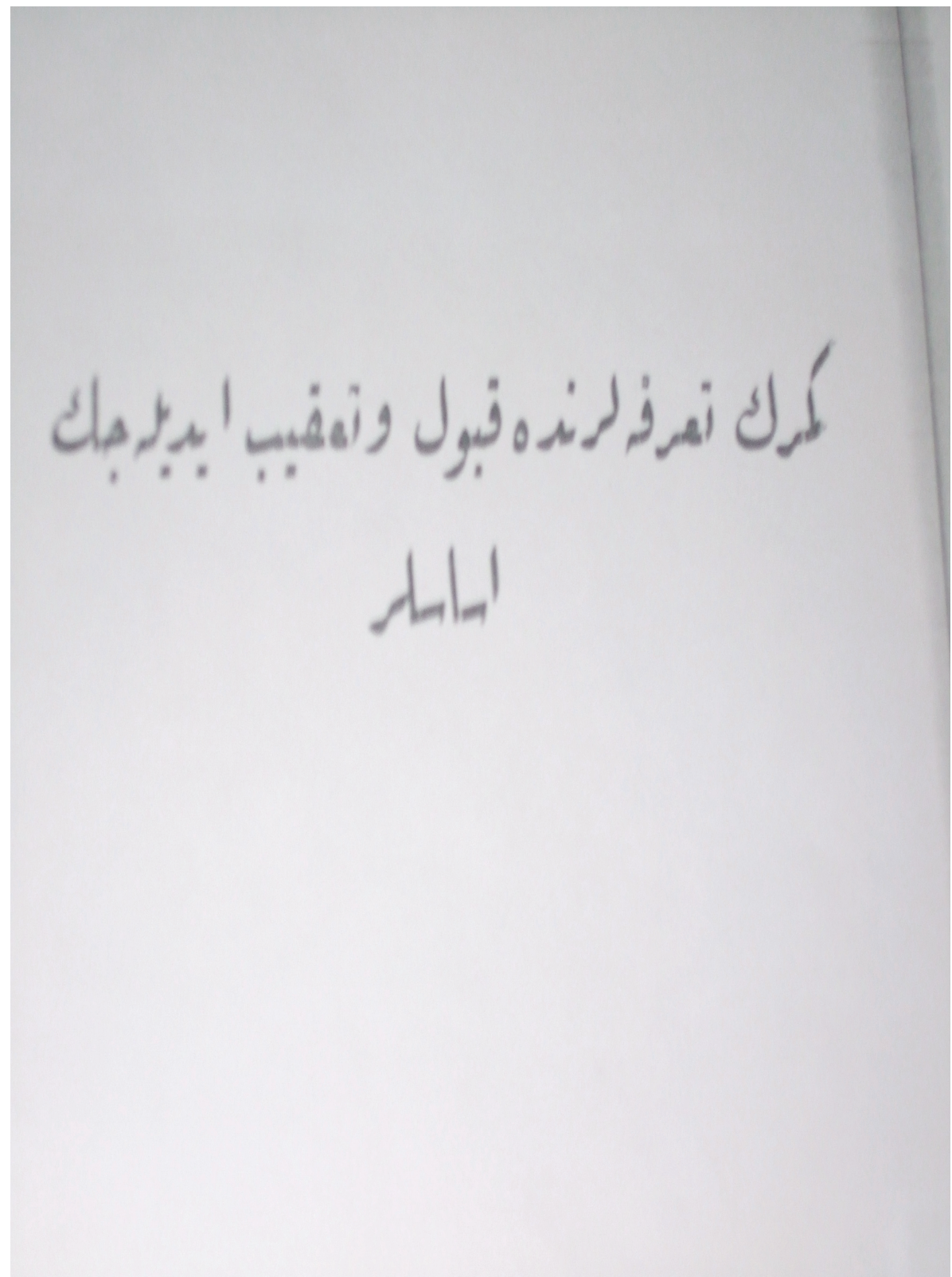




\section{EK.2.}

\section{Âli İktisat Meclisi Raporları}

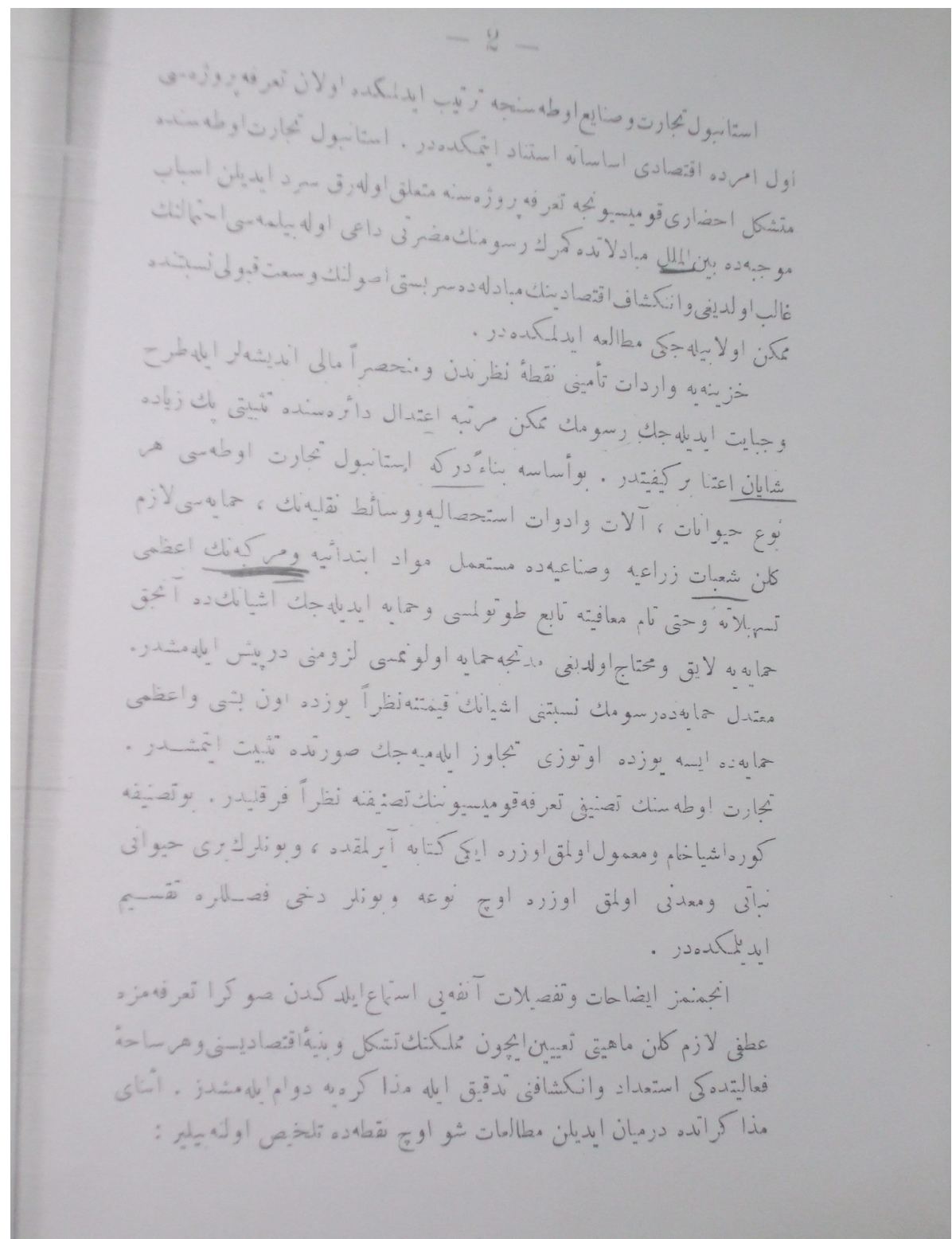




\section{EK.3.}

\section{Âli İktisat Meclisi Raporları}

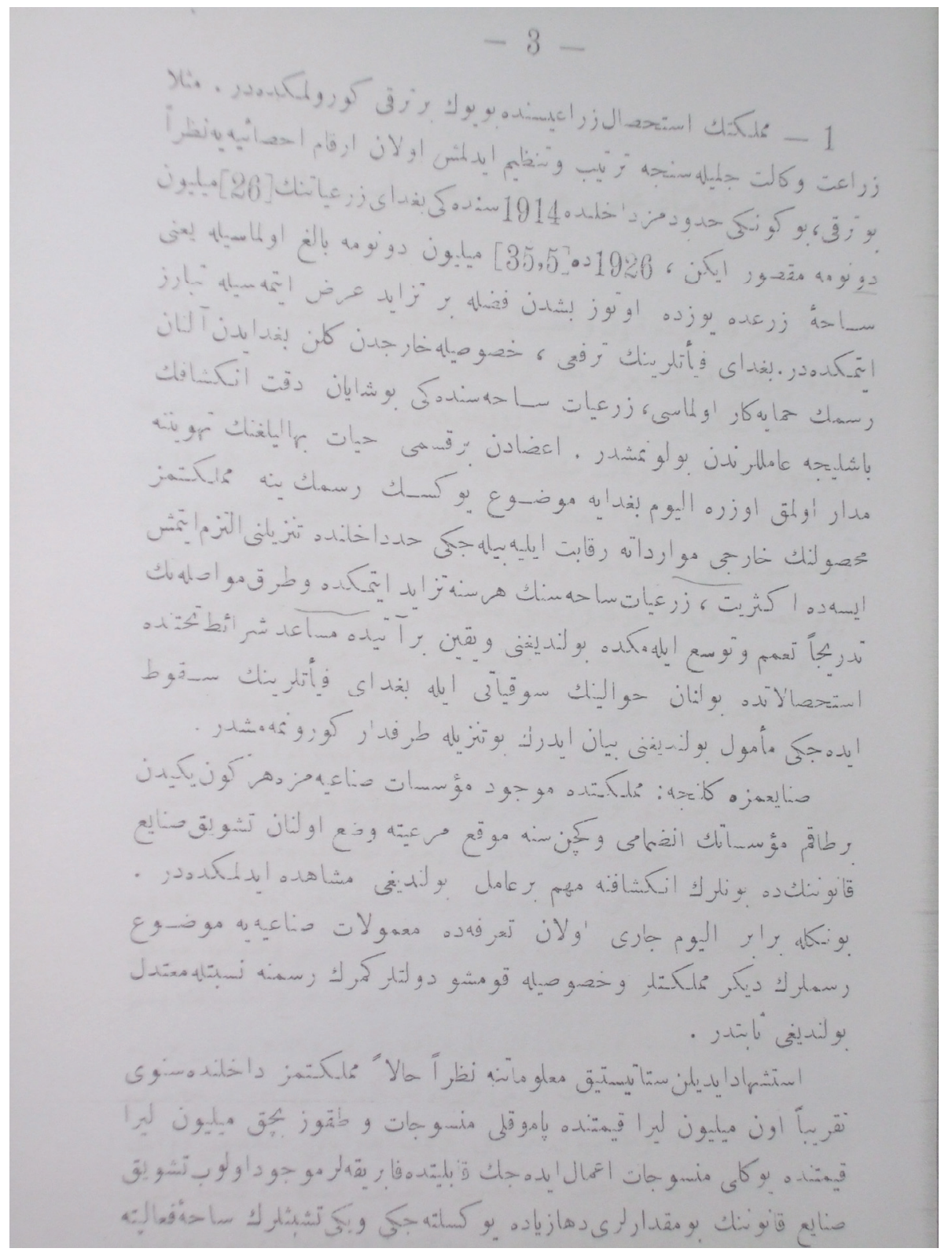


EK.4.

\section{Türkiye'nin Ödemeler Dengesi}

\begin{tabular}{|c|c|c|c|c|c|c|}
\hline AKTİFLER & 1928 & 1929 & 1930 & 1931 & 1932 & 1933 \\
\hline $\begin{array}{l}\text { 1. Emtia } \\
\text { (ihraç) }\end{array}$ & 221.222 .000 & 190.545 .000 & 186.570 .000 & 156.683 .000 & 113.801 .000 & 100.484 .000 \\
\hline $\begin{array}{l}\text { 2. Külçe } \\
\text { Halinde } \\
\text { Altın, Nukud } \\
\text { ve Evrakı } \\
\text { Nakdiye }\end{array}$ & & & & & & \\
\hline $\begin{array}{l}\text { 3.Yabancilara } \\
\text { Yapılan } \\
\text { Ticari } \\
\text { Hizmetler }\end{array}$ & 18.133 .000 & 18.716 .000 & 15.598 .000 & 13.229 .000 & 10.894 .000 & 11.330 .000 \\
\hline $\begin{array}{l}\text { 4. Faizler ve } \\
\text { Temettüler }\end{array}$ & 880.000 & 1.000 .000 & 1.000 .000 & 523.000 & 448.000 & 434.000 \\
\hline $\begin{array}{l}\text { 5. Hususi } \\
\text { İşlemlerden } \\
\text { Doğan Diğer } \\
\text { Gelirler }\end{array}$ & 12.580 .000 & 8.577 .000 & 7.260 .000 & 4.614 .000 & 5.408 .000 & 9.717 .000 \\
\hline $\begin{array}{l}\text { 6. Hükümet } \\
\text { İşlemleri }\end{array}$ & 6.480 .000 & 12.167 .000 & 15.646 .000 & 13.632 .000 & 3.843 .000 & 3.193 .000 \\
\hline $\begin{array}{l}\text { 7. Sermaye } \\
\text { Akımı }\end{array}$ & 10.500 .000 & 21.985 .000 & 1.670 .000 & 1.173 .000 & 4.487 .000 & 1.503 .000 \\
\hline 8. Kalan & 15.810 .000 & 90.718 .000 & 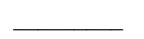 & 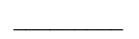 & 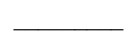 & 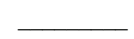 \\
\hline Toplam & 285.605 .000 & 343.708 .000 & 227.744 .000 & 189.854 .000 & 138.881 .000 & 126.661 .000 \\
\hline
\end{tabular}

Kaynak: Âli İktisat Meclisi Raporları, A7, A8, A10, A13, A15 ve İstatistik Yıllığ1, No.7 1933-1934, s.468 
EK.5.

\section{Türkiye'nin Ödemeler Dengesi}

\begin{tabular}{|c|c|c|c|c|c|c|}
\hline PASİFLER & 1928 & 1929 & 1930 & 1931 & 1932 & 1933 \\
\hline $\begin{array}{l}\text { 1. Emtia } \\
\text { (ithali) }\end{array}$ & 248.532 .000 & 283.976 .000 & 172.053 .000 & 152.660 .000 & 101.209 .000 & 88.734 .000 \\
\hline $\begin{array}{l}\text { 2. Külçe Halinde } \\
\text { Altın, Nukud ve } \\
\text { Evrakı Nakdiye }\end{array}$ & & & & 8.378 .000 & 2.071 .000 & \\
\hline $\begin{array}{l}\text { 3. Yabancilardan } \\
\text { Alınan Ticari } \\
\text { Hizmetler }\end{array}$ & 5.194 .000 & 6.785 .000 & 2.846 .000 & 4.328 .000 & 1.071 .000 & 619.000 \\
\hline $\begin{array}{l}\text { 4. Faizler ve } \\
\text { Temettüler }\end{array}$ & 7.000 .000 & 6.000 .000 & 7.660 .000 & 1.861 .000 & 810.000 & 1.245 .000 \\
\hline $\begin{array}{l}\text { 5. Hususi } \\
\text { İşlemlerden Doğan } \\
\text { Diğer Gelirler }\end{array}$ & 10.970 .000 & 11.725 .000 & 11.709 .000 & 7.918 .000 & 10.942 .000 & 4.686 .000 \\
\hline 6. Hükümet İşlemleri & 9.979 .000 & 19.939 .000 & 10.239 .000 & 9.097 .000 & 10.128 .000 & 5.959 .000 \\
\hline 7. Sermaye Akımı & 3.930 .000 & 15.463 .000 & 9.276 .000 & 4.082 .000 & 5.619 .000 & 6.193 .000 \\
\hline 8. Kalan & & & 13.961 .000 & 1.530 .000 & 7.031 .000 & 19.225 .000 \\
\hline Toplam & 285.605 .000 & 343.708 .000 & 227.744 .000 & 189.854 .000 & 138.881 .000 & 126.661 .000 \\
\hline
\end{tabular}

Kaynak: Âli İktisat Meclisi Raporları, A7, A8, A10, A13, A15 ve İstatistik Y1llı̆̆ 1 , No.7 1933-1934, s.468 